\title{
PENGOLAHAN AIR LIMBBAH DOMESTIK DENGAN TANAMAN AIR PADA PARAMETER COD, BOD DAN DO
}

Dzaki Hamzah Wasita

\author{
Jurusan Teknik Lingkungan, Fakultas Arsitektur Lanskap dan Teknologi Lingkungan, \\ Universitas Trisakti, Jakarta, Indonesia
}

Email korespondensi: $\underline{\text { dzaki08215020@ std.trisakti.com }}$

\begin{abstract}
ABSTRAK
Sebagian besar air dipakai sebagai air untuk pembilas, sebagai contoh air bersih yang digunakan untuk mandi dan cuci. Namun, kebutuhan akan air baku yang besar tidak diikuti dengan persediaan air baku, baik secara kuantitas maupun kualitas. Salah satu cara untuk mengatasi masalah ini adalah dengan memanfaatkan kembali (reuse) efluen hasil pengolahan air limbah. Pada penulisan ini cara mengelolah air limbah domestik menggunakan sistem lahan basah buatan yang menggunakan tanaman air dalam skala lapangan. Penulisan ini bertujuan mengetahui efisiensi penurunan kadar Chemical Oxygen Demand (COD), Biological Oxygen Demand (BOD) dan Dissolved Oxygen (DO) yang terkandung dalam limbah cair domestik pada suatu daerah. Metode penulisan dengan cara mengaklamatisasi tanaman selama 12 hari sebelum ditanamkan ke lahan basah buatan kemudian mengukur efisiensi penurunan kadar efluen. Hasil percobaan menunjukkan bahwa dengan menggunakan tanaman air dalam sistem lahan basah buatan dapat penyisihan kandungan pencemar dalam air limbah dengan waktu tinggal 2 hari. Keunggulan pengolahan air limbah dengan sistem ini selain kualitas hasil air pengolahan yang sesuai baku mutu air limbah domestik juga dapat meningkatkan kualitas tanah.
\end{abstract}

Kata Kunci: Air limbah domestik; Lahan basah buatan; Tanaman Air

\section{PENDAHULUAN}

Secara biologis pengolahan air limbah domestik yang mengandung bahan organik dapat direduksi dengan beberapa jenis pengolahan, yaitu anaerobik, aerobik atau gabungan dari beberapa proses tersebut. Pengolahan air limbah secara biologis mempunyai kelebihan dan kekurangannya. Dengan demikian diperlukan cara menggunakan teknologi yang murah, ekonomis, mudah, sederhana, tepat guna pada operasional ataupun pemeliharannya.

Di negara-negara berkembang, pembuangan air limbah langsung ke badan air (danau, sungai, dll.), Dan kesulitan mendapatkan air bersih merupakan tantangan besar pemerintah. Pembuangan air limbah tanpa melalui pengolahan memiliki dampak besar pada keanekaragaman perairan, kesehatan masyarakat, dan eutrofikasi. Oleh karena itu, pengolahan air limbah perlu dilakukan sebelum air limbah dibuang ke badan air penerima (Rininta, 2018) . (Penggunaan tumbuhan air dalam sistem lahan basah buatan sebagai alternatif sarana pengolahan air limbah, pada beberapa negara telah banyak digunakan. Namun di Indonesia, belum terlalu dikenal metode ini, karena materi dan publikasi mengenai kemampuan tumbuhan air tersebut masih kurang. Lahan basah buatan mempunyai keefektifan dalam mendegradasi polutan air limbah dipengaruhi oleh jenis tanaman dan media filter yang digunakan. Lahan basah buatan terbagi atas dua jenis pola aliran, yang pertama sistem aliran atas permukaan dan sistem aliran bawah permukaan. Lahan basah buatan juga dapat diklasifikasikan sebagai aliran vertikal maupun aliran horizontal.

Berdasarkan morfologi, tumbuhan air sangat cocok untuk pengolahan dengan sistem lahan basah buatan. Tumbuhan air memiliki sistem perakaran yang banyak yang dapat menyerap zat organik di bagan air. Sedangkan tumbuhan air sangat banyak dan tumbuh subur di perairan. Berdasarkan hal di atas, maka perlu dilakukan peneltian mengenai kemapuan tumbuhan air dalam sistem lahan basah buatan yang diharapkan dapat menurunkan parameter BOD dan COD pada air limbah domestik.

Tujuan penulisan karya ilmiah ini dilakukan dengan untuk mengetahui kualitas air limbah domestik pada sistem lahan basah buatan dengan Mengetahui efektifitas tanaman air, Manfaat dari penulisan ini adalah sebagai alternative pilihan bagi pemerintah dan masyarakat dalam penerapan teknologi pengolahan air limbah dan sebagai referensi perkembangan ilmu pengetahuan sebagai referensi, acuan dan pertimbangan penulisan selanjutnya. 


\section{TINJAUAN PUSTAKA}

Air limbah domestik adalah air buangan dari rumah tangga, industri ataupun tempattempat umum lain yang mengandung bahan yang dapat mencemari lingkungan dan kehidupan manusia (Metcalf \& Eddy dalam Supradata, 2005). Menurut Keputusan Menteri Lingkungan Hidup Nomor 112 Tahun 2003 tentang Baku Mutu Air Limbah Domestik pada Pasal 1 ayat 1 menyebutkan bahwa air limbah domestik adalah air limbah yang berasal dari usaha dan atau kegiatan permukiman, rumah makan, perkantoran, perniagaan, apartemen dan asrama. Air limbah domestik yang tidak diolah dapat menyebabkan masalah kerusakan lingkungan di sungai, danau dan badan air publik lainnya. Ini telah meningkat pesat selama dekade terakhir. Sumber air utama adalah polusi air limbah domestik (Setiyawan, 2018)

Pada proses pengolahan air limbah dengan teknologi lahan basah buatan dapat terjadi melalui proses fisika, kimia, dan biologis yang merupakan hubungan antara mikroorganisme . Lahan basah buatan terbagi menjadi dua tipe yaitu lahan basah buatan tanaman air muncul dan tanaman air mengapung. Tanaman air muncul yaitu memiliki kedalaman yang sangat dangkal, berada pada kisaran 0,1 - 0,6 m.(Abidi, 2007) sedangkan tanaman air mengapung dapat mencapai kedalaman 0,5 1,8 meter. Teknologi lahan basah buatan dipilih untuk menangani permasalahan limbah domestik dikarenakan teknologi ini merupakan teknologi yang murah biayanya, tidak memerlukan teknologi canggih untuk mengoperasikannya, dan tidak memerlukan operator khusus dalam mengoperasikannya (Stottmeister, 2014).

Tanaman memiliki peranan penting dalam penyisihan polutan pada lahan basah buatan, diantaranya adalah untuk menyediakan lingkungan aerobik disekitar akar. (Tuti, 2015). Proses pengolahan yang terjadi pada sistem ini adalah filtrasi, adsorbs oleh mikroorganisme dan adsorbs terhadap tanah dan bahan organik oleh akar-akar. Floating Aquatic Plant System atau tanaman air terapung memanfaatkan jenis tanaman air yang hidup terapung di permukaan air dengan posisi terjerat, sehingga memungkinkan tanaman tersebut untuk menyerap zat-zat yang diperlukan terutama bahan terlarut yang terjadi di bawah perakaran tanaman dapat meningkatkan kapasitas pengolahan dan memelihara kondisi aerobik yang di perlukan untuk proses biologis, dibawah permukaan air.

Air limbah yang dapat digunakan dalam penulisan ini adalah air limbah domestik dari pemukiman warga yang mana belum ada pengolahan air limbah dan air limbah yang langsung dibuang melalui saluran pembuangan dan selanjutnya mengalir ke sungai. Untuk media lahan basah dapat menggunakan tanah rawa yang diambil langsung kemudian dibersihkan dari kotoran seperti kaca, plastik, dan batu. Tanaman air memiliki beberapa jenis dan banyak di jumpai disekitar lahan basah alami di Indonesia. Salah satu jenis tanaman air adalah Vetiveria sp. Tanaman ini tidak mudah mati, memiliki daya tahan yang kuat dan serta memiliki akar serabut yang lebat sehingga penyerapan terhadap terhadap unsur hara yang dibutuhkan relative lebih besar besar. (Roongtanakiat, 2007)

\section{Tabel 1. Penelitian Terdahulu Mengenai Lahan Basah Buatan}

\begin{tabular}{llll}
\hline No. & \multicolumn{1}{c}{ Penulis } & \multicolumn{1}{c}{ Judul } & \multicolumn{1}{c}{ Pembahasan } \\
\hline 1. & Lita & Pengolahhan Air & Penulisan ini menggunakan tanaman rumput \\
Darmayanti & Limbah Domestik & mending (Fimbristylis globulosa) untuk \\
& ,Manyuk & dengan Sistem & menurunkan pH, COD, dan TSS dengan waktu \\
Fauzi, dan & Lahan Basah & detensi 2, 3, 4, dan 5 hari. Hasil penulisan lahan \\
Bagus Hajri & Buatan Aliran & basah buatans yang digunakan dapat \\
(2013) & Bawah Permukaan & menurunkan nilai pH rata-rata 23,3-29,3\%, COD \\
& & 27,7-56,9\% dan TSS 84,4-90,8\% dengan waktu \\
& & detensi terbaik adalah 5 hari
\end{tabular}




\begin{tabular}{|c|c|c|c|}
\hline No. & Penulis & Judul & Pembahasan \\
\hline 2. & $\begin{array}{l}\text { Mega } \\
\text { Anggraeni, } \\
\text { Henna Rya } \\
\text { Sunoko, \& } \\
\text { Hadiyanto } \\
(2013)\end{array}$ & $\begin{array}{l}\text { Pengolahan } \\
\text { Effluent dari IPAL } \\
\text { Industri Farmasi } \\
\text { dengan Sistem } \\
\text { Lahan Basah } \\
\text { Buatan Aliran } \\
\text { Bawah Permukaan }\end{array}$ & $\begin{array}{l}\text { Penulisan ini menggunakan Cyperus } \\
\text { alternifolius dan Canna india untuk menurunkan } \\
\text { kandungan BOD, COD, ammonia, dan nitrit dari } \\
\text { efluen IPAL industry farmasi. Hasil penulisan } \\
\text { menunjukan bahwa reaktor dengan tanaman } \\
\text { Cyperus alternifolius dengan media kerikil lebih } \\
\text { efektif dengan pencapaian efisiensi adalah } \\
\text { sebesar } 98,9 \% \text { untuk BOD; } 95,8 \% \text { untuk COD; } \\
86 \% \text { untuk ammonia; dan } 97,23 \% \text { untuk nitrit }\end{array}$ \\
\hline 3 & $\begin{array}{l}\text { M. G. } \\
\text { Prathap, } \\
\text { dkk. (2014) }\end{array}$ & $\begin{array}{l}\text { Leachate } \\
\text { Treatment Using } \\
\text { Lahan basah } \\
\text { buatans Technique }\end{array}$ & $\begin{array}{l}\text { Penulisan ini menggunakan tanaman Typha unuk } \\
\text { mengolah kandungan BOD dan COD pada air } \\
\text { lindi. Hasil dari penulisan ini didapatkan } \\
\text { efisiensi penyisihan BOD dan COD masing- } \\
\text { masing adalah sebesar 70\%-75\% dan } 75 \% \text { dalam } \\
\text { waktu detensi } 5 \text { hari }\end{array}$ \\
\hline 4. & $\begin{array}{l}\text { Nualchavee } \\
\text { Roongtanak } \\
\text { iat, } \\
\text { Tanasun } \\
\text { Nirunrach, } \\
\text { Supitcha } \\
\text { Chanyotha } \\
\text { dan Diti } \\
\text { Hengchaov } \\
\text { anich } \\
\text { (2003) }\end{array}$ & $\begin{array}{l}\text { Uptake of Heavy } \\
\text { Metals in Landfill } \\
\text { Leachate by } \\
\text { Vetiver Grass }\end{array}$ & $\begin{array}{l}\text { Penulisan ini membahas pemanfaatan tanaman } \\
\text { Vetiveria zizanioides untuk air lindi. Tanaman } \\
\text { yang digunakan untuk konsentrasi air lindi } 100 \% \\
\text { hanya bertahan hidup } 80-85 \text { hari setelah } \\
\text { penanaman. Hal tersebut disebabkan kandungan } \\
\text { polutan air lindi yang melebihi kapasitas toleran } \\
\text { tanaman Vetiveria zizanioides. Setelah } 30 \text { hari, } \\
60 \text { hari dan } 90 \text { hari diperiksa kandungan logam } \\
\text { berat ( } \mathrm{Zn}, \mathrm{Cu}, \mathrm{Ni} \text {, dan } \mathrm{Cr} \text { ) pada sampel tanaman. } \\
\text { Diketahui hasil rata-rata kadar logam terbesar } \\
\text { ada dalam akar disusul oleh bagian tunas. }\end{array}$ \\
\hline 5. & $\begin{array}{l}\text { Tazkiaturri } \\
\text { zki (2016) }\end{array}$ & $\begin{array}{l}\text { Efisiensi } \\
\text { Penyisihan } \\
\text { Senyawa Karbon } \\
\text { Pada Efluen IPAL } \\
\text { Bojongsoang } \\
\text { dengan Lahan } \\
\text { basah buatan Tipe } \\
\text { Subsurfacce } \\
\text { Horizontal Flow : } \\
\text { Studi Potensi Daur } \\
\text { Ulang Air Limbah }\end{array}$ & $\begin{array}{l}\text { Konsentrasi efluen setelah air efluen IPAL } \\
\text { Bojongsoang diolah dengan menggunakan lahan } \\
\text { basah buatan menunjukkan terjadi peningkatan } \\
\text { kualitas air sebagai pertimbangan daur ulang air } \\
\text { limbah. Dengan menggunakan hasil kinerja } \\
\text { rangkaian reaktor tiga (T.latifolia } \\
\text { +aerasi,S.grossus, G.max) diperoleh konsentrasi } \\
\text { efluen yaitu COD berada pada rentang 6-17 } \\
\text { mg/L; BOD berada pada rentang 1-4 mg/L telah } \\
\text { memenuhi standar kualitas air kelas } 2 \\
\text { berdasarkan baku mutu PP } 82 / 2001 \text { dan } \\
\text { berpotensi untuk digunakan sebagai daur ulang } \\
\text { air limbah }\end{array}$ \\
\hline
\end{tabular}

\section{PENUTUP}

Dari uraian diatas menunjukkan bahwa dengan menggunakan tanaman air dalam sistem lahan basah buatan dapat penyisihan kandungan pencemar dalam air limbah dengan waktu tinggal 2 hari, efisiensi penyisihan COD 77,6\% - 91,8\%, BOD 47,4\% - 91,6\% dan DO 33,3\%$83,3 \%$. Keunggulan pengolahan air limbah dengan sistem lahan buatan ini adalah teknologi yang sederhana, murah, mudah, tepat guna, ekonomis serta operasional dan pemeliharannya yang tidak memerlukan tenaga khusus.

\section{UCAPAN TERIMA KASIH}

Selama melaksanakan penulisan Karya Ilmiah ini penulis mendapatkan materi, bantuan serta bimbingan dari beberapa pihak. Oleh sebab itu penulis ingin mengucapkan terima kasih kepada Rositayanti Hadisoebroto, selaku dosen pembimbing I, Melati Ferianita Fachrul, selaku 
dosen pembimbing II. Teman-teman dan keluarga yang selalu memberikan dukungan dan doa sehingga penulis dapat menyelesaikan Karya ilmiah ini.

\section{DAFTAR PUSTAKA}

Abidi, Samira. 2007. Comparative pilot study of the performances of two wetland wastewater treatment hybrid system. Water Research and Technologies Centre, Tunisia.

DOI : 10.1016/j.desal.0000.00.000

Anggraeni, M., Sunoko, H. R, \& Hadiyanto, H. 2013. Pengolahan Effluent dari IPAL Industri Farmasi dengan Sistem Lahan Basah Buatan Aliran Bawah Permukaan.

Darmayanti, L., Fauzi, M., \& Hajri, . (2013). Pengolahan Air Limbah Domestik dengan Sistem Lahan Basah Buatan Aliran Bawah Permukaan. Prosiding SNTK TOPI, 149-157

Ferina, Tuti. 2015. Efisiensi Penyisihan Krom Heksavalen Pada Air Lindi Dengan Metode Lahan Basah Buatan Menggunakan Vetiveria Zizaniodes. Skripsi Sarjana Universitas Indonesia

Metcalf and Eddy, 2005 "Wastewater Engineering : Treatment, Disposal, and Reuse ". Mc Graw Hill Inc. New York

Purwati,dkk. 2007. Potensi Dan Pengaruh Tanaman Pada Pengolahan Air Limbah Pulp Dan Kertas Dengan Sistem Lahan Basah. Jurnal berita Selulosa, Vol. 42 (2). Hal. 45 - 53.

Triananda N, Rininta. 2018. Selection Of Domestic Wastewater Treatment Technology Alternative Using Life Cycle Assessment (Lca) Approach (Case Study: Settlement Area Of Riverbank Karang Mumus Of Samarinda City, East Kalimantan). Indonesia Journal of Urban and Environmental Technology. 1(2) 164-184

DOI : http://dx.doi.org/10.25105/urbanenvirotech.v1i2.2825

Roongtanakiat, N., Tangruangkiat, S., Meesat,R. 2007. Utilization of Vetiver Grass for Removal of Heavy Metlas from Industrial Wastewater. Departement of Applied Radiation and Isotopes, Kasetrat University, Thailand.

Stottmeister, U. 2014. Effects of plants and microrganisms in wetland for wastewater treatment. UFZ Centre for Environmental Research, Germany.

DOI : 10.1016/j.biotechadv.2003.08.010

Supradata, 2005 “Pengolahan Limbah Domestik Menggunakan Tanaman Hias Cyperus alternifolius dalam Ssstem Lahan Basah Aliran

Tazkiaturrizki. 2016. Efisiensi Penyisihan Senyawa Karbon Pada Efluen IPAL Bojongsoang dengan Lahan basah buatan Tipe Subsurfacce Horizontal Flow : Studi Potensi Daur Ulang Air Limbah. Jurnal Indonesian Journal of Urban and Environmental Technology, Universitas Trisakti.

Vymazal, 2008 "Removal of Organic in Lahan basah buatans With Horiontal Sub-Surface Flow : A review of The Field Experience" Institute of System Biology and ecology, Cezh Republic

Zurita, 2008 "Treatment of Domestic and Production of Commercial Flowers in Vertical and Horizontal Subsurface-Flow System Lahan basah buatan" Centro auniversity de la Cienaga, Mexico

Prathap, M. G., Reymond, D., Sudarsan, J. S,m \& Deepthha, d. V. 2014. Leachate Treatment using Lahan basah buatans Technique. Journal of Environmental Science, Toxicology and Food Techhnology (IOSR-JESTFT) Vol. 8, Ver. IV, 7-9

VA. V., Setiyawan. A.S. dan Soewondo. 2018. The Characteristics Of Domestic Wastewater From Office Buildings In Bandung, West Java, Indonesia.). Indonesia Journal of Urban and Environmental Technology. 1(2) 199-214

DOI : http://dx.doi.org/10.25105/urbanenvirotech.v1i2.2826 